\title{
Life cycle of the pelagic goby Aphia minuta (Pisces: Gobiidae)*
}

\author{
M. IGLESIAS ${ }^{1}$ and B. MORALES-NIN ${ }^{2}$ \\ ${ }^{1}$ IEO - Centro Oceanográfico de Baleares, Muelle de Poniente s/n, Apdo. 291, 07080 Palma de Mallorca, Spain. \\ E-mail: magdalena.iglesias@ba.ieo.es \\ ${ }^{2}$ CSIC/UIB - Institut Mediterrani d'Estudis Avançats, Campus Universitari, 07071 Palma de Mallorca, Spain.
}

\begin{abstract}
SUMMARY: Reproductive aspects of the transparent goby Aphia minuta ( $\mathrm{n}=2977,14-45 \mathrm{~mm}$ total length (TL)) were studied in Majorcan waters, western Mediterranean, during the fishing season (December to April) from 1985 to 1993. Male:female sex ratio was $1: 1$. Size at first maturity was $38 \mathrm{~mm}$ TL for females and $34 \mathrm{~mm}$ TL for males. Oocyte size-frequency distribution indicated that A. minuta is a single spawner. Fecundity of A. minuta ranged from 935 to 2648 oocytes. The breeding season extended from December to April with a peak in March. After a single reproduction at 5-6 months of age, most of the specimens disappeared from the fishing areas. Recruitment to the fishing area occurred in late December and early January (14-24 mm TL, age 2-3 months). On the other hand, the hatch date back-calculated from the age in days and the date of capture of individuals of A. minuta during the fishing season, indicated a spawning peak in autumn (September-October), six months after the peak of observed spawning. Schools of A. minuta were detected by acoustic methods, during the fishing season (winter-spring) in fishing areas (5-40 $\mathrm{m}$ depth), principally inside bays, and during the rest of the year (summer and autumn) in deeper areas $\left(40-90 \mathrm{~m}\right.$ ), outside bays, with water temperatures between 13 and $16^{\circ} \mathrm{C}$ and a high seasonal productivity in each depth range. Therefore, we propose that $A$. minuta has two annual cohorts in the western Mediterranean, corresponding to two main spawning in spring and autumn, respectively. Life history pattern indicated that we only know the winter cohort resulting from the autumn spawning. Meanwhile the summer cohort (spring spawning) grows and reproduces in deeper areas not being targeted by the fishery. Indirect validation is provided from information from other areas. The relevance of the life cycle is discussed in relation to fishery management.
\end{abstract}

Key words: Aphia minuta, coastal zone, fishery, reproduction, acoustic surveys, Majorca, Mediterranean Sea.

\section{INTRODUCTION}

An important small-scale fishery, using a special surrounding net that is hauled over the bottom, exists off the island of Majorca (Fig. 1) in winter (December to April), on sand and mud bottoms inside bays, between 5 and 40 metres depth (Iglesias and Martorell, 1992; Iglesias et al., 1994). The target species of this fishery is the small pelagic trans-

\footnotetext{
*Received May 12, 2000. Accepted January 9, 2001.
}

parent goby A. minuta (Risso, 1810) and by-catches are two similar goby species, Pseudaphia ferreri (De Buen and Fage, 1908) and Cristallogobius linearis (von Düben, 1845). The fishery exploits the schools that these species form close to the bottom (Iglesias and Martorell, 1992). Such a small-scale fishery is conducted in Spain off Murcia (MartínezBaño et al., 1993), as well as in Italy in the Ligurian Sea (Relini et al., 1996), in the northern Tyrrhenian Sea (Serena et al., 1990; Baino et al., 1996) and in the central and southern Adriatic Sea (Froglia and 


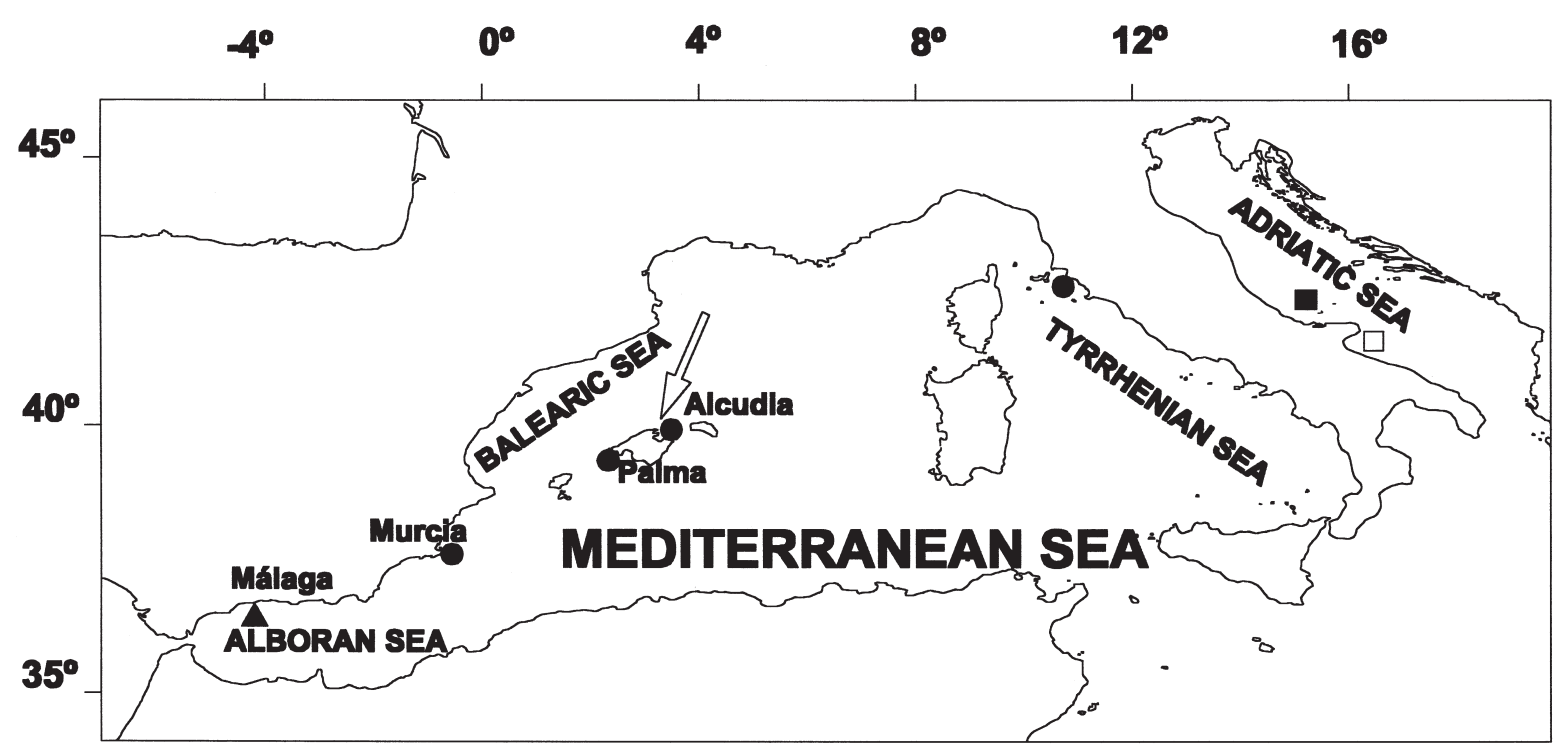

FIG. 1. - Commercial fishing areas for A. minuta in the Mediterranean Sea, showing study site (arrowed). (s) fishery disappeared by overexploitation; (D) seasonal winter fishery; (n) whole year fishery; (q) bycatch on juvenile clupeiform fishery.

Gramitto, 1989; Froglia et al., 1998; Rizzoli, 1983; Ungaro et al., 1994) (Fig. 1). In Majorca the fishery finishes at the end of March when the abundance decreases sharply and is no longer profitable for the fleet, which then switches to catch lobster (Palinurus vulgaris).

The annual catch of $A$. minuta obtained in five months, represents about $4.5 \%$ in value of the commercial landings in the fish market of Palma (sale centre for catches from the whole island). In recent years landings have decreased dramatically (Fig. 2), evidencing a risk of collapse of the fishery. A collapse occurred in Malaga (Fig. 1) ten years ago when A. minuta was drastically reduced by the fishery. In this case, there was a substitution with anchovy (Engraulis encrasicholus) and sardine (Sardina pilchardus) larvae and juveniles (Garcia et al., 1981) as target species. However, this is a forbidden fishery at present.

The transparent goby A. minuta is common in the European Atlantic from Gibraltar to the coasts of Norway and the Baltic Sea, and in the Mediterranean, including the Black Sea and the Azov Sea (Tortonese, 1975). A. minuta is a neotenic pelagic species (not superior to $60 \mathrm{~mm}$ in total length in the Mediterranean Sea) that feeds on zooplankton, principally copepods, cirripede larvae and mysids (Miller, 1986). Age and growth studies carried out on the island of Majorca, after validation of otolith daily increments, showed that the commercial fish-

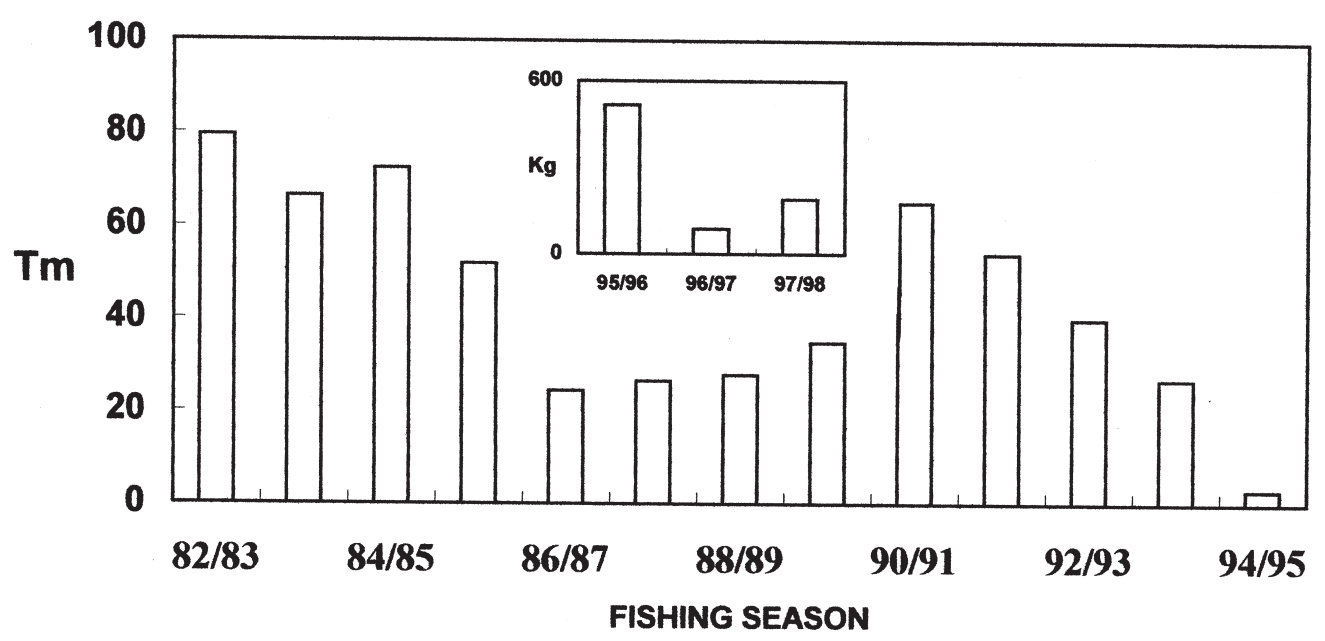

FIG. 2. - Landings of A. minuta in Majorca from the 1982/83 to 1994/95 fishing season (Dec-Apr) in metric tons (Tm) and from $1995 / 96$ to 1997/98 in kilograms $(\mathrm{Kg})$. 
TABLE 1. - Reproduction data on A. minuta; * from back-calculated hatch-dates.

\begin{tabular}{|c|c|c|}
\hline Spawning season & Area & Author and year \\
\hline March-April & Palma Bay (Majorca) & De Buen (1940) \\
\hline April-May & Northern Thyrrenian & Serena et al. (1990) \\
\hline March-August & Northern Thyrrenian & Baino et al., 1996 \\
\hline May-August & Adriatic Sea & $\begin{array}{l}\text { Froglia and Gramitto } \\
\text { (1989) }\end{array}$ \\
\hline May-July & Black Sea & Borcea (1933) \\
\hline June-July & North Sea & Fage (1918) \\
\hline June-August & Ria de Aveiro (Portugal) & Arruda et al. (1993) \\
\hline October & W Mediterranean & $\begin{array}{l}\text { MERSEL94 cruise } \\
\text { (IEO) }\end{array}$ \\
\hline December-April & Majorca & (this study) \\
\hline June-November* & Majorca & (this study) \\
\hline
\end{tabular}

ery exploits fish from 2 to 8 months old (Iglesias $e t$ al., 1997). This species probably never lives longer than one year (De Buén, 1931).

Available data on reproduction are limited and somewhat contradictory, indicating a rather varied spawning season (Table 1), from December to March in the western Mediterranean, in April in the northern Tyrrhenian, in May in the Adriatic, from May to July in the Black Sea and from June to August in the Atlantic ocean. The eggs are demersal and have the characteristic of adhering to hard substrata, stones, shells or other objects (De Buén, 1931; pers. obs.).

The aim of the present study was to determine the reproductive biology of $A$. minuta in Majorcan sea waters, in relation to other biological and environmental information, in order to obtain insights into the life history of this poorly known species. For this, length composition by sex, monthly sex ratio and length-weight relationships from seven fishing seasons have been analysed for a description of the population trends. In addition, data from the 1992-93 fishery were used to study size at first maturity, fecundity and recruitment. Additional data on the population were obtained by means of acoustic surveys in winters 1993 to 1998 and summers 1996 to 1998 . The results obtained are discussed in relation to the seasonal appearance of the species in the Bay fishing grounds and to decreased landings.

\section{MATERIAL AND METHODS}

\section{Biological sampling}

Fish samples were collected weekly from landings of the commercial small-scale fishery, during the fishing season (December to March-April), between 1985 and 1993. A total of 2977 specimens of A. minuta were analysed. Total length (TL) was measured to the mm below. Fish wet weight was determined to the nearest $0.01 \mathrm{~g}$. Sex was determined by observation of the gonads under the compound microscope at $\mathrm{x} 60$. Sex ratio was expressed as a percentage of males:females in the sample. Chisquare $\left(\chi^{2}\right)$ analysis was used to determine whether the sex ratio by length interval and by month deviated from 1:1 (Sokal and Rohlf, 1981).

For the 1992-93 fishing season length distribution by sex and maturity for each fish $(n=456)$ were assessed by five stages: immature, maturing, ripe, running ripe or spent (Miller, 1961). The observation of ripe individuals was used as an indication of the onset of breeding. In order to determine the size at first maturity (length at which $50 \%$ of the fish became mature), "ripening" and "non-ripening" fish were studied for both sexes. Size at first maturity was obtained after adjusting for a log normal distribution on the curve showing the percentage of mature specimens as a function of size class, using the programme LIONOR (J. Lleonart, Institut de Ciencies del Mar Barcelona, unpublished data).

Fecundity was estimated on female ovaries $(\mathrm{n}=$ 42) just prior to spawning (March). The ovaries were weighed to the nearest $0.1 \mathrm{mg}$ and were preserved in buffered formalin $(\mathrm{pH}=8.4)$. All the oocytes of the gonad were enumerated to study the absolute ovarian fecundity and the diameter of 50 oocytes per female was measured to the nearest 0.01 $\mathrm{mm}$ by using a micrometer scale projected on the overhead screen of a compound microscope 40x. Regression analyses were made to determine the relationship of fecundity to the fish length, body weight and ovary weight.

In order to determine age, sagittal otoliths were extracted from a representative sample $(n=241)$ covering the fish size range $(14-44 \mathrm{~mm})$. The increments in the otoliths of A. minuta are laid down with daily periodicity (Iglesias et al., 1997). Thus, they were used for age determination following standard techniques (Morales-Nin, 1992). Once the age was determined, the hatch-date was back-calculated from the date of capture and the age in days. The age obtained was approximate, and lacked a correction factor corresponding to the period between hatching and initiation of increment deposition.

\section{Acoustic Surveys}

Acoustic surveys were carried out in January $(1993,94,95,96,97,98)$ in the most important fish- 


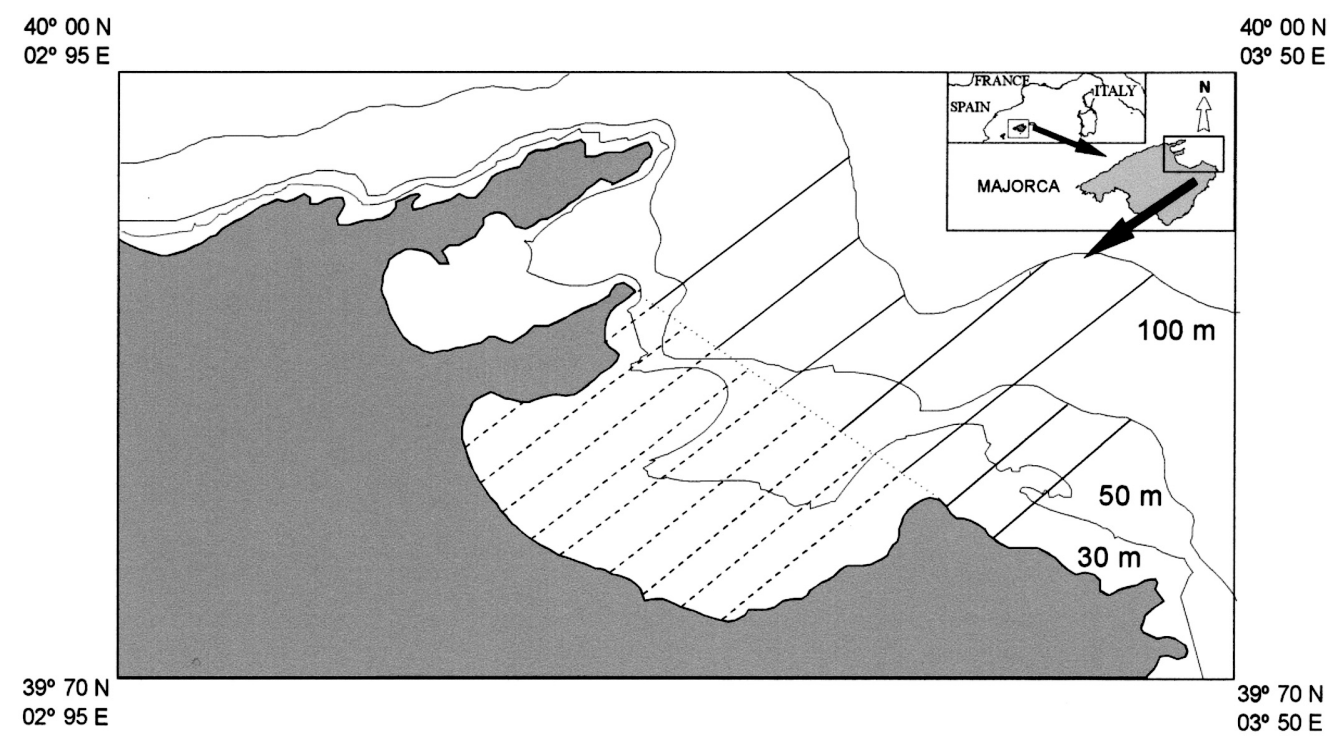

FIG. 3. - Acoustic survey area (Alcudia Bay, Majorca) and transects. Dotted lines: winter surveys; black lines: summer surveys.

ing zone of the island, the Bay of Alcudia, to determine the presence and distribution of recruits of $A$. minuta (Fig. 3) in a range depth of 5-40 m. A 38 $\mathrm{KHz}$ paper echosounder (Skipper 815, Simrad) was used, together with a ceramic transducer towed body (10 x 20; $11^{\circ}$ beam width) (Iglesias and Miquel, 1998). In July $(1996,97,98)$ the same strategy was applied on tracks outside the Bay in a range depth between 40 and $100 \mathrm{~m}$ (Fig. 3), to detect the presence of recruits of A. minuta from the spring spawning. A. minuta schools cause a distinctive mark on the echogram paper or display when using acoustic methods, but it was not possible to validate the detection by means of fishing because of depth. Indirect validation was obtained by observation using scuba-divers at $30 \mathrm{~m}$ outside the bay (Fig. 3). Thus, the summer results are only indicative.

\section{RESULTS}

The monthly length composition by sex for the 1992-93 period showed differences between sexes (Fig. 4). The number of sexually undifferentiated fish decrease by month, although they continue being found every month, with length always smaller than $33 \mathrm{~mm}$. The polymodal length frequencies showed a rapid evolution of the female length, while males which were initially bigger grew at a slower rate with the larger fish disappearing at the end of the fishing season (March). The monthly mean length (TL) increased: December $27.4 \mathrm{~mm}$ (standard deviation s.d.: $4.8 \mathrm{~mm}$ ); January $30.5 \mathrm{~mm}$ (s.d.: 3.7 $\mathrm{mm}$ ); February $33.0 \mathrm{~mm}$ (s.d.: $5.3 \mathrm{~mm}$ ) and March: $35.0 \mathrm{~mm}$ (s.d.: $4.7 \mathrm{~mm}$ ) with a parallel increase in gonadal development. The percentage of mature individuals of both sexes showed the start of maturity in the second half of December (10\% mature individuals) with a subsequent rapid increase, reaching the maximum spawning peak in March $(78 \%$ mature individuals) (Fig. 5). The smallest mature female found was $28 \mathrm{~mm}$ TL and the smallest mature male $25 \mathrm{~mm}$ TL. The fish with $\mathrm{TL}<23 \mathrm{~mm}$ corresponding to less than 3 months of age, are mainly not sexually differentiated (Fig. 4). The length-weight parameters are included in Table 2. There is positive allometry without clear differences between sexes

The overall ratio of males to females in the catches of A. minuta for the seven studied seasons (Table 3) show a marked inter-annual variability which is significantly different from 1:1 (statistical analysis

TABLE 2. - A. minuta length-weight parameters (a and b) obtained for the whole study period and for the 1992-93 fishing season by sexes. M: males; F: females; I: indeterminates; TL: total length (in $\mathrm{mm}) ; \mathrm{n}=$ number of individuals.

\begin{tabular}{|c|c|c|c|c|c|}
\hline Fishing season & $\mathrm{a}$ & $\mathrm{b}$ & $r^{2}$ & TL range & $\mathrm{n}$ \\
\hline $1985-86$ & 0.000329 & 3.79 & 0.92 & $19-40$ & 141 \\
\hline $1986-87$ & 0.003014 & 3.19 & 0.94 & $18-40$ & 100 \\
\hline $1987-88$ & 0.001875 & 3.32 & 0.89 & $22-43$ & 160 \\
\hline $1989-90$ & 0.000226 & 3.90 & 0.96 & $19-41$ & 220 \\
\hline 1990-91 & 0.001613 & 3.32 & 0.93 & $12-45$ & 351 \\
\hline $1991-92$ & 0.000963 & 3.45 & 0.94 & $18-45$ & 526 \\
\hline $1992-93$ & 0.000407 & 3.69 & 0.96 & $16-44$ & 467 \\
\hline $1992-93(\mathrm{M})$ & 0.000492 & 3.64 & 0.95 & $23-44$ & 182 \\
\hline $1992-93(\mathrm{~F})$ & 0.000529 & 3.62 & 0.95 & $22-44$ & 168 \\
\hline $1992-93$ (I) & 0.000633 & 3.54 & 0.92 & $16-38$ & 117 \\
\hline
\end{tabular}



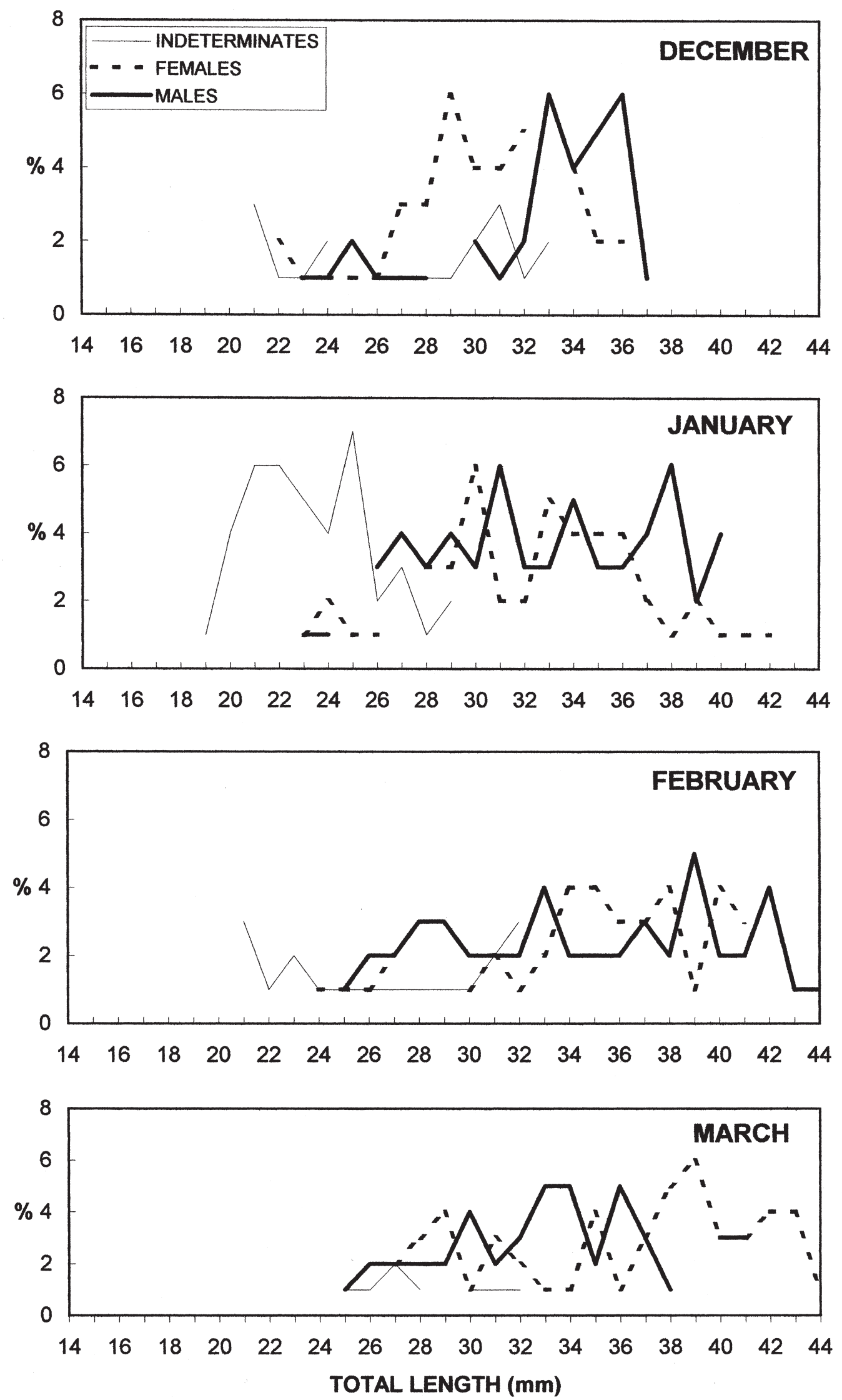

FIG. 4. - Monthly length composition by sex of A. minuta for the 1992-93 period (TL mm). 


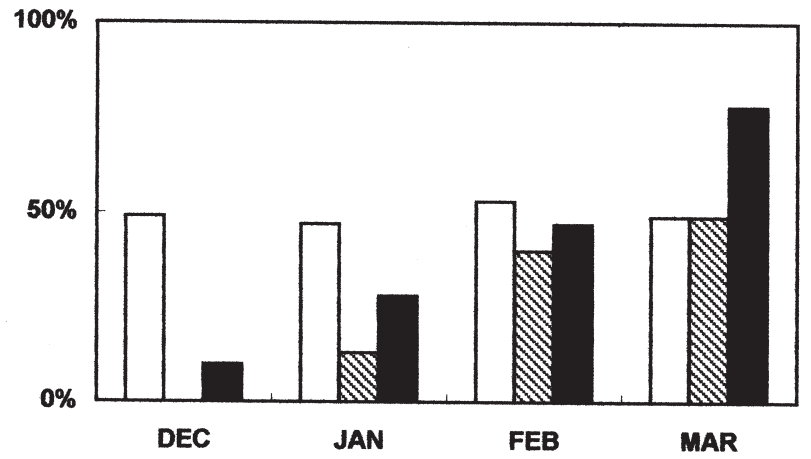

FIG. 5. - Evolution of mature A. minuta by sex during the fishing season. Black bars: total matures; white bars: \% of males with TL $\geq$ $34 \mathrm{~mm}$; striped bars: $\%$ of females with TL $\geq 38 \mathrm{~mm}$.

TABLE 3. - Sex ratio of A. minuta during the fishing period (December- March) of the years 1985 to 1993; n: individuals number; **: p $<0.05 ; *: \mathrm{p}<0.01$.

\begin{tabular}{lccc}
\hline $\begin{array}{l}\text { Fishing season } \\
\text { (Dec- Apr) }\end{array}$ & Males (n) & Females (n) & Sex ratio \\
\hline & & 535 & $1: 1.8 * *$ \\
$1985 / 86$ & 304 & 92 & $1: 0.9$ \\
$1986 / 87$ & 105 & 307 & $1: 1.6 *$ \\
$1987 / 88$ & 187 & 157 & $1: 1.3$ \\
$1989 / 90$ & 123 & 183 & $1: 1.1$ \\
$1990 / 91$ & 160 & 150 & $1: 0.9$ \\
$1991 / 92$ & 138 & 168 & \\
$1992 / 93$ & 182 & & \\
\hline
\end{tabular}

TABLE 4. - A. minuta monthly sex ratio (males:females) from December to April during the years 1985 to 1993 ; *: $\mathrm{p}<0.05$; **: $\mathrm{p}<0.01$.

\begin{tabular}{llllllll}
\hline Month & $85 / 86$ & $86 / 87$ & $87 / 88$ & $89 / 90$ & $90 / 91$ & $91 / 92$ & $92 / 93$ \\
\hline DEC & $1: 5.0 * *$ & $1: 1.6$ & $1: 2.5 * *$ & $1: 1.1$ & $1: 2.3 * *$ & $1: 1.1$ \\
JAN & $1: 3.0 * *$ & $1: 0.7 *$ & $1: 3.2 * *$ & $1: 1.4$ & $1: 0.9$ & $1: 0.8$ & $1: 0.8$ \\
FEB & $1: 1.4 * * 1: 1$ & $1: 1.8 *$ & $1: 1$ & $1: 1.8$ & $1: 0.8$ & $1: 0.7$ \\
MAR & $1: 1.5 * *$ & $1: 0.9$ & $1: 0.7 *$ & $1: 1.5$ & $1: 1$ & $1: 1$ & $1: 1.2$ \\
APR & $1: 1.3$ & & & & $1: 1.8$ & & \\
\hline
\end{tabular}

by $\left.\chi^{2}\right)$ in the 1985-1986 and 1987-1988 fishing seasons. The monthly sex ratio (Table 4) show interannual variability with significant differences for some years and months. Females are more abundant in December, at the beginning of the fishing season.

Length at which $50 \%$ of the population attain maturity is reached at $38 \mathrm{~mm}$ (s.d.: $2.44 \mathrm{~mm}$ ) in females, and $34 \mathrm{~mm}$ TL (s.d.: $2.40 \mathrm{~mm}$ ) in males (Fig. 6). The percentage of individuals that equal or surpass the length at first maturity for each month of the fishing season is $50 \%$ for the males, whereas the females increase throughout the season from December (0\%) to March (50\%) (January: $13 \%$ and February: 40\%) (Fig. 5).

The absolute fecundity of $A$. minuta $(38-45 \mathrm{~mm}$ TL) from Majorca was between 935 and 2648

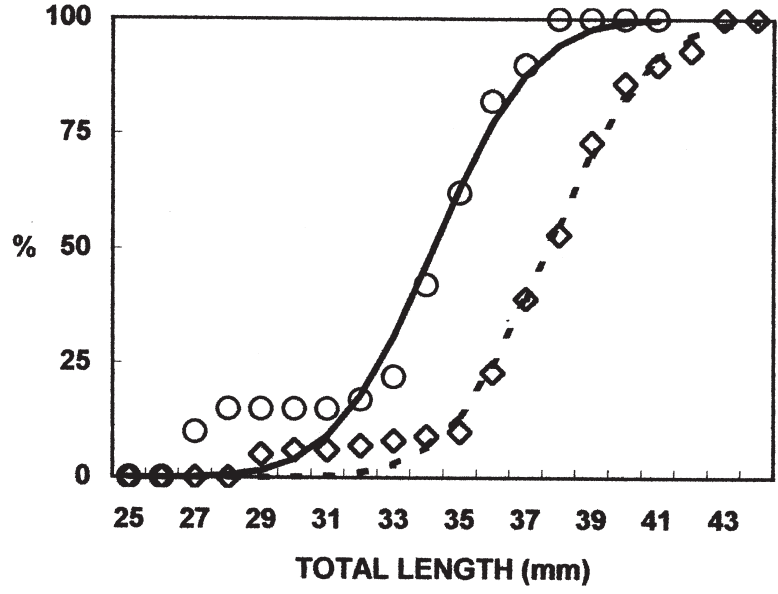

FIG. 6. - Curves of mature population by length for A. minuta $(\bigcirc=$ males; $\diamond=$ females).

oocytes per female with an average of 1615 oocytes. The diameter of the oocytes measured in March, ranged between 0.12 and $0.60 \mathrm{~mm}$ (average: 0.34 $\mathrm{mm}$, s.d. $=0.12 \mathrm{~mm}$ ). For each individual there was only one mode in the ovaries indicating that A. minuta is a single spawner.

The number of oocytes from an individual is independent of the fish total length $\left(r^{2}=0.0146\right)$, the fish total weight $\left(r^{2}=0.0031\right)$ and the gonad weight $\left(\mathrm{r}^{2}=0.0418\right)$. Therefore, a relationship does not exist between the corporal dimensions of the female and its fecundity. However, a relationship exist between the size of the gonad $(\mathrm{mg})$ and the diameter of the oocyte $(\mathrm{mm})\left(\mathrm{r}^{2}=0.8570\right)$.

The determined ages were between 63 and 250 days, for a length interval of 14 to $44 \mathrm{~mm}$. The hatch-dates, estimated by means of back-calculation from the reading of daily growth increments in otoliths of A. minuta and the date of capture of the individuals, extended from June to November, with a maximum in October (45\% of the hatches) and a second peak in September (20\%). A small peak was also observed in July (15\%) (Fig. 7).

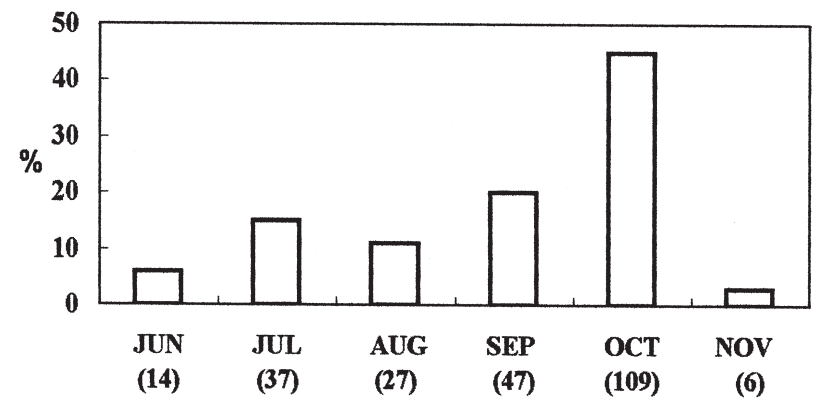

FIG. 7. - Back-calculated hatch-dates for A. minuta individuals caught in the fishing season (December-March). Number of fish in brackets. 


\section{DISCUSSION}

Observation of the fishery during the winter months showed that individuals of A. minuta are recruited to the fishery by forming schools in the period of December-January, with lengths between 14 and $24 \mathrm{~mm}$ TL corresponding to ages between two and three months (Iglesias et al., 1997). At this time, a large number of the fish are sexually undifferentiated. They undergo a rapid somatic growth throughout the season, accompanied by gonadal maturation, and reach the period of maximum spawning in March. The size at first maturity for males (34 mm TL) and for females (38 mm TL) corresponded to an approximate age of five-six months. When reaching 7-8 months of age (between 38 and $45 \mathrm{~mm} \mathrm{TL}$ ) they have all already reproduced, as the observation of the gonadal development demonstrates. A. minuta appears to be a single spawner, since the observation of female ovaries only shows oocytes of a single size that increases evenly throughout the season. Spawning is an unique event for individual fish which have a low fecundity, but spawning can occur several times at the population level. This is typical behaviour in gobies (Miller, 1984). Studies carried out in the Adriatic all year long (Froglia and Gramitto, 1989) estimate between 1500 and 7000 oocytes (for fish in the length range $31-56 \mathrm{~mm}$ TL), with an average diameter of the oocytes in mature females of $0.4 \mathrm{~mm}$. Compared with our results, this shows larger lengths linked to a larger number of oocytes, contrast to the independence of fish length and fecundity found in Majorca. The disappearance of $A$. minuta inside the bays suggests either that they had migrated elsewhere after spawning, or that a high proportion had died. Mortality after the first and only period of spawning occurs in several gobies (Bouchereau et al., 1989; Daoulas et al., 1993).

The differences found in the sex ratio are probably caused by a differential maturity that conditions the aggregation of individuals ready to reproduce. The greater number of females at the beginning of the season could be because the females are recruited in advance to the fishery caused by their faster growth rate (Iglesias et al., 1997) and earlier larger size. A. minuta in the Mediterranean generally shows a larger proportion of females compared to males at the beginning of the season (De Buén, 1931, 1940; Llabrés and Martorell, 1984) or during the whole fishing season (Martínez-Baño et al., 1993).

The back-calculated hatch-dates for the specimens caught during the fishing season (DecemberMarch) showed a peak in the autumn with $65 \%$ of the hatch-dates in September-October. These hatchdates might be biased due to length-selective mortality that might lead to some error (Campana and Jones, 1992).

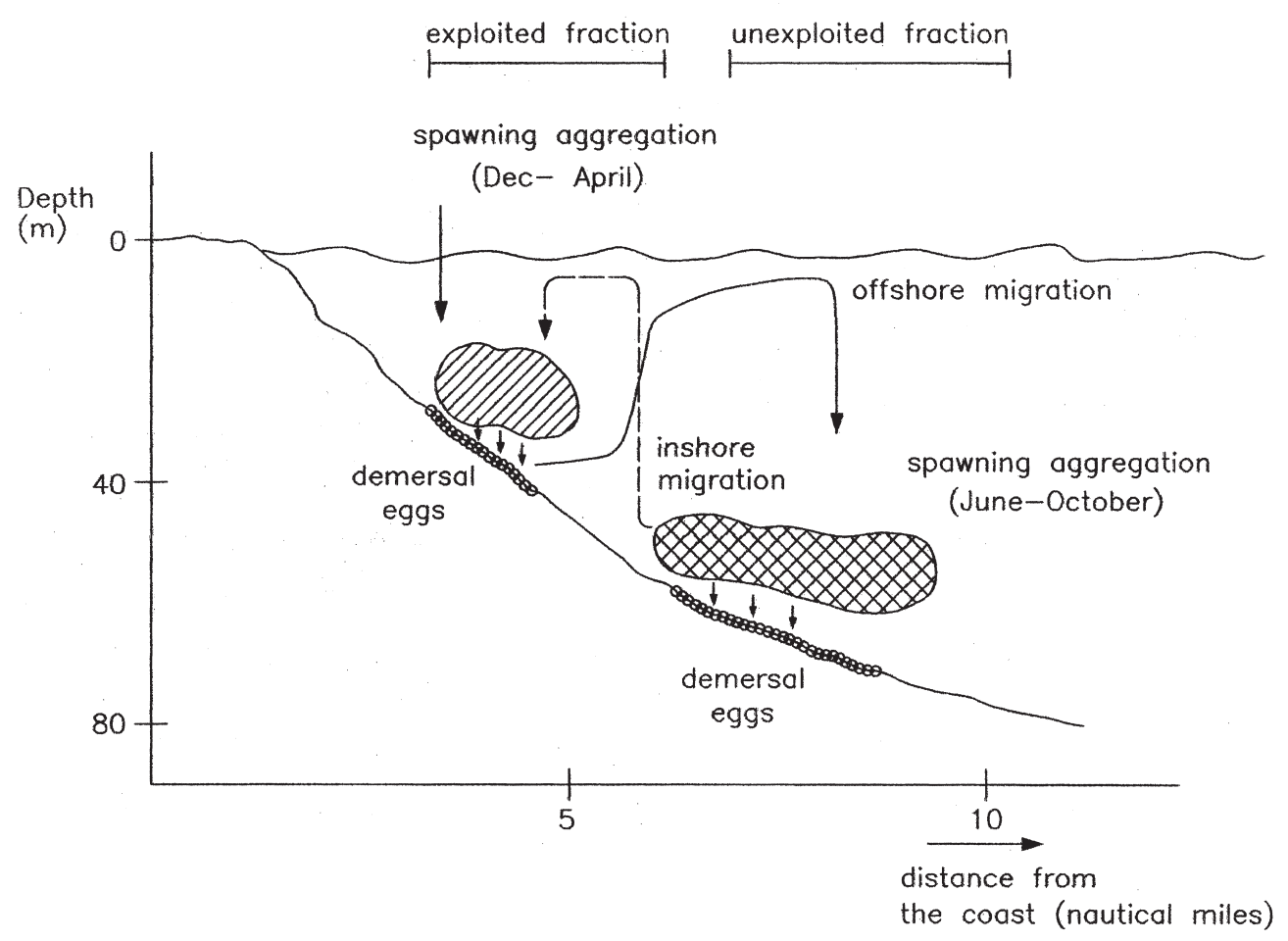

FIG. 8. - Proposed life cycle for A. minuta in Majorcan waters and for the Mediterranean sea. 
The difference of approximately six months between the observed spawning peak (March) and the peak of back-calculated spawning (SeptemberOctober), leads us to hypothesise the existence of two annual cohorts for this species. They would be the result of two main spawnings, one observed in early spring, that will not be caught by the fishery, and another in autumn that will be caught during their reproductive aggregation from December to March (Fig. 9). Although the two maximum spawning peaks are situated in spring and autumn, spawning continues throughout the whole year at a lower level, since ripe females can be found during every fishing month (from December to May) and backcalculated spawning occurs in the rest of the months of the year (from June to November).

The available information on reproduction (Table 1), length composition of the catches, ichthyoplankton and occasional captures, corroborates this proposed life cycle. For instance, gradual growth of individuals is observed throughout the season for the population as a whole, but a continuous incorporation of small length specimens is also observed (Fig. 4), confirming the hypothesis of a continuous spawning throughout the year in Majorcan waters. In addition, the presence of larvae has been detected throughout most of the year. In oceanographic cruises carried out during 1985-1988 (BALEARIC IVIII, CSIC) on the Balearic continental shelf, $A$. minuta larvae were found in stations located outside the bays between the months of March and November (Alemany, 1997).

Water temperature observed during the fishing period for A. minuta in the Majorca bays at depths between 5 and $40 \mathrm{~m}$, varied between 13 and $16^{\circ} \mathrm{C}$ (López-Jurado, 1990). From March a rapid increase in the temperature occurs until temperatures close to $27^{\circ} \mathrm{C}$ are reached in the warmest months of the year, from July to September. Hydrographical conditions similar to those of the winter fishing areas (5-40 m), are found in summer at greater depths, between 70 and $90 \mathrm{~m}$ (López-Jurado, 1990). Therefore, we suppose that the second annual cohort of A. minuta resulting from the March-April spawning would leave the bays, conditioned by certain thermal requirements, and move to deeper waters. A. minuta shows this type of migration in areas such as the Ria de Aveiro (Portugal) (Arruda et al., 1993) and in the central Adriatic (Mancini and Cavinato, 1969). This migration linked to the temperature of the superficial waters is found in other gobies such as Pomatoschistus minutus (Bouchereau et al., 1990) in the Gulf of Lyons, and for G. cobitis, G. ophiocephalus and G. cruentatus (Casabianca and Kiener, 1969) in Corsica. It does not seem that depth is a limiting factor for $A$. minuta, since it has been found between depths of one metre in the Ria de Aveiro (Portugal) (Arruda et al., 1993) and $97 \mathrm{~m}$ in the Columbretes Islands (Spanish Mediterranean) (MEDIT-0595/IEO trawling cruise).

Thus, spawning would be carried out at the bottom of the bays in March-April, and outside them in September-October. The pelagic larvae would be helped in their displacements towards the outside of the bays in spring and towards the inside in autumn, by the existing currents in the areas (López-Jurado, 1994). The migratory displacement conditioned by the temperature of the water would carry this species to areas in which the phytoplankton production is greater in summer (Durán and Jansá, 1986). The areas of high phytoplanktonic production coincide with the areas of high zooplanktonic production, which would resolve the necessary energy contribution for the growth of A. minuta.

In Majorca occasional catches of A.minuta have occurred in summer, while tunas (Thunnus thynnus) have been caught with stomachs full of A. minuta (fishermen, pers. com.). Similarly, catches of this goby $(\mathrm{n}=101)$ have occurred in waters of southern Spain (Málaga) during October 1994 (MERSEL94; IEO) at a depth of $80 \mathrm{~m}$, on a mud and coralline bottom, with lengths ranging between 36 and $42 \mathrm{~mm}$ TL (mode $39 \mathrm{~mm}$ ), with most of the females being mature. This catch, although not carried out in the study area, seems to confirm the existence of the second cohort of this goby with a maximum spawning in October.

In the Adriatic Sea, A. minuta is found during the whole year and in the August catches two modes are observed in the distribution of size frequencies, one ( $80 \%$ in number) corresponding to the recruitment of the individuals (16-38 mm) from a June spawning and another $(20 \%)$ corresponding to the individuals $(40-54 \mathrm{~mm})$ that are left after the post-spawning mortality (Froglia and Gramitto, 1989). In the southern Adriatic (Gulf of Manfredonia), fishing of juvenile clupeiformes is carried out during the night with trawling gear. In the catches, variable percentages of A. minuta appear according to the month, with the highest being those in December (55\%) and July (35\%) (Rizzoli, 1983). These two abundance peaks coincide with the two recruitment periods calculated for A. minuta around Majorca (Table 1). Acoustic surveys have helped to locate the distribution of this 
species due to the special characteristic of this pelagic gobiid of forming schools during the day near the bottom, giving a clear signal to the echosounder.

We conclude, therefore, that temperature conditions the spawning area and distribution of A. minu$t a$, as in many other gobies (Fonds, 1973). Consequently, they are located during winter-spring at depths between 5 and $40 \mathrm{~m}$, on bottoms of sand and gravel, principally inside bays, and during summerautumn at greater depths $(60-80 \mathrm{~m})$ over coralline and mud bottoms, always at temperatures between 13 and $16^{\circ} \mathrm{C}$. The knowledge of the life cycle is relevant because in the last years the landings of the species in Majorca have decreased notably (Fig. 2). Sound management should take into account that exploitation is carried out on the recruits of the summer spawning and that the life spawn is shorter than previously expected. Moreover, the exploitation of the reproductive schools adds more risk to this fishery, requiring cautious levels of exploitation.

\section{ACKNOWLEDGEMENTS}

We are grateful to the scientific leaders of BALEARIC I-VIII, MERSEL 94 and MEDIT0595 surveys for the information provided, and to Chris Rodgers for the translation of the manuscript. The samples were obtained from the commercial fishery, thus no experiments were carried out.

\section{REFERENCES}

Alemany, F. - 1997. Ictioplancton del mar Balear: resultados de las campañas Baleares, Miver, Canales de Ibiza, Proyecto Bahía y Proyecto Radiales. PhD Thesis University of the Balearic Islands, pp 608.

Arruda, L.M., J.N. Azevedo and A.I. Neto. - 1993. Abundance, age-structure and growth, and reproduction of Gobies (Pisces; Gobiidae) in the Ria de Aveiro Lagoon (Portugal). Estuar. Coast. Shelf Sci., 37: 509-523.

Baino R., R. Auteri and L. Donati. - 1996. Crescita e reclutamento alla pesca del rossetto. Biol. Mar. Medit. 3(1): 525-526.

Borcea, I. - 1933. Révision systemátique et distribution géographique des Gobidés de la Mer Noire et particulièrement des eaux Roumaines. Annales Scient. Univ. De Jassy, tom XIX, fasc. 1-4.

Bouchereau, J.L., J.C. Joyeux, J.A. Tomasini, J.P. Quignard. 1989. Cycle sexuel, fécondités et condition de Pomatoschistus microps (Kroyer, 1838) (Gobiidés) dans la lagune de Mauguio, France. Bull. Ecol., 20(3):193-202.

Bouchereau, J.L., J.P. Quignard, J.A. Tomasini, J.C. Joyeux and C.H. Capape. - 1990. Cycle sexuel, condition et ponte de Pomatoschistus minutus (Pallas, 1770) (Gobiidae) du Golfe du Lion, France. Cybium 14 (3):251-267.

Campana, S.E. and C.M. Jones. - 1992. Analysis of otolith microstructure data. Canad. Spec. Publ. Fish. Aqua. Sci., 117: 73-100.

Casabianca, M.L. and A. Kiener. - 1969. Gobiidés des étangs cors- es: systématique, écologie, régime alimentaire et position dans les chaînes trophiques. Vie Milieu 20A(3): 611-634.

Daoulas, C.H., A.N. Economou, T.H. Psarras and R. Barbieri-Tseliki. - 1993. Reproductive strategies and early development of three freshwater gobies. J. Fish Biol., 42: 749-776.

De Buén, F. - 1931. Notas a la familia Gobiidae. Observaciones sobre algunos géneros y sinopsis de las especies ibéricas. Not. Resúm. Inst. Esp. Oceanogr., (Serie II) 54: 1-76.

De Buén, F. - 1940. Les Gobiidae pélagiques ou vivant sur les fonds d'algues calcaires de l'Europe Occidentale. Bull. Inst. Océanogr. Monaco, 790: 1-96.

Durán, M. and J. Jansá. - 1986. Distribution verticale des chlorophylles planctoniques dans les eaux voisines de l'île de Majorque. Rapp. Com. Inter. Mer Méditerranée 30(2): 184.

Fage, L. - 1918. Shore fishes. Report Danish Oceanogr. Exped. 1908 - 1910. Medit. and adjac. Seas. II a.3.

Fonds, M. - 1973. Sand gobies of the Dutch Wadden Sea (Pomatoschistus, Gobiidae, Pisces). Netherl. J. Sea Res., 6: 417-78.

Froglia, C. and M.E. Gramitto. - 1989. La pesca del Rossetto (A. minuta) nel medio Adriático. Nova Thalassia 10(Suppl): 447-455.

Froglia, C., M. La Mesa, E. Arneri and M.E. Gramitto. - 1998. La pesca del rossetto nel compartimento marittimo di Pescara (Medio Adriatico). Biol. Mar. Medit., 5 (3): 503-512.

García, A., J. Crespo and J.C. Rey. - 1981. Management of living resources in the Mediterranean coastal area. Studies Rev General Council Mediterranean 58: 131-147.

Iglesias, M., E.B. Brothers and B. Morales-Nin. - 1997. Validation of daily increment deposition in otoliths. Age and growth determination of A. minuta (Pisces: Gobiidae) from the north-west Mediterranean. Mar. Biol., 129: 279-287.

Iglesias, M. and J.M. Martorell. - 1992. La pesquería de góbidos en las Islas Baleares. Inform. téc. Inst. esp. Oceanogr., 116: 1-18.

Iglesias, M., E. Massutí, O. Reñones and B. Morales-Nin. - 1994. Three small-scale fisheries based on the island of Majorca (NW Mediterranean). Boll. Soc. Hist. Nat. Balears, 37: 33-57.

Iglesias, M. and J. Miquel. - 1998. Assessment of the A. minuta stock (Pisces: Gobiidae) by acoustic methods from the Bay of Alcudia (Majorca, western Mediterranean). Sci. Mar., 62(1): $19-25$.

Llabrés, M. and J.M. Martorell. - 1984. La pesquería de artes menores. Comunidad Autónoma de las Islas Baleares. Mimeo: 218-246.

López-Jurado, J.L. - 1990. Masas de agua alrededor de las Islas Baleares. Bol. Inst. esp. Oceanogr., 6(2): 3-20.

López-Jurado, J.L. - 1994. Corrientes en la bahía de Alcudia durante el periodo Junio 1993 a Marzo 1994. Informe GESA.mimeo: 1-121.

Mancini, L. and P.G. Cavinato. - 1969. Osservaziones morfologiche e biometriche sul Gobiide A. minuta nell'Adriatico Centrale e alcune considerazioni in rapporto alla pesca. Boll. Pesca Piscic. Idrobiol., 24: 49-60.

Martínez-Baño, P., F. Vizuete and J. Mas. - 1993. The fishery of the transparent goby A. minuta (Risso, 1810) on the fishing grounds off Murcia (South-eastern Spain). Sci. Mar., 57: 199-205.

Miller, P.J. - 1961. Age, growth and reproduction of the rock goby, Gobius paganellus L., in the Isle of Man. J. Mar. Biol. Ass. U.K., 41: 737-769.

Miller, P.J. - 1984. The tokology of gobioid fishes. In: G.W. Potts and R.J. Wootton (eds.), Fish reproduction: Strategies and Tactics, pp 119-153. London, Academic Press.

Miller, P.J. - 1986. Gobiidae. In: PJP Whitehead et al. (eds.), Fishes of the North-Eastern Atlantic and of the Mediterranean, Vol. III, pp 1019-1085. UNESCO, París.

Morales-Nin, B. - 1992. Determinación del crecimiento de peces óseos en base a la microestructura de los otolitos. FAO Documento técnico Pesca 322: 1- 58.

Relini, G., C. Cima, F. Garibaldi, G. Palandri, M. Relini, G. Torchia. - 1996. Una risorsa costiera: il rossetto Aphia minuta mediterranea De Buen, 1931 (Osteichthyes: Gobidae). Biol. Mar. Medit. 3(1): 205-213.

Rizzoli, M. - 1983. Considérations sur la pêche du "Bianchetto" en Adriatique. FAO Fish. Repp., 290: 233-234.

Serena, F., A. Auteri, A. Abella and R. Baino. - 1990. The transparent goby fishery in the Northern Tyrrhenian Sea. Rapp. Proc.verb. Réu. Com. Inter. Explo. sci. Mer Méditerranée, 32: 257.

Sokal, R.R. and F.J. Rohlf. - 1981. Biometria: Principios y métodos estadísticos en la investigación biológica. Universidad del 
Estado de Nueva York, Stony Brook. H. Blume Ediciones. $1^{\text {a }}$ Edición española: 832 pp.

Tortonese, E. - 1975. Ostheichtyes. Pesci ossei. Parte seconda. Calderini, Bologna 11: 290-340.

Ungaro, N., N. Casavola, G. Marano and E. Rizzi. - 1994.
"Bianchetto" and "Rossetto" fry fisheries in the Manfredonia Gulf: effort exerted and catch composition. Oebalia 20: 99-106.

Scient. ed.: M. Harmelin-Vivien 